\title{
Preface:
}

\section{The Art of Being Free}

Reading frees itself from the soil that determined it. . . Emancipated from places, the reading body is freer in its movements. It thus transcribes in its attitudes every subject's ability to convert the text through reading and "run it" the way one runs traffic lights.

- Michel de Certeau

The way of theorizing pursued in these pages is informed by my work as a teacher. Since I began that work, much of my time has been given to teaching multiple versions of an introductory course in political theory. The course examines some of the concerns at the center of this bookfreedom and equality, democracy and subjection, individuality and difference, the places and practices of politics. I try to show why these topics matter, arguing that the American polity confronts them all the time, if not always in the most self-conscious, satisfying, or generous of ways. The course works, and I come to feel I am pursuing a calling as well as punching a clock, only when this attempt to bring the world into the classroom succeeds. Political theory becomes worth doing when theories from the past speak to the present. Perhaps this is obvious. But it is a lesson I had to learn on the job. I learned it from the students in my very first class, and their instruction changed my way of both teaching and reading "canonical" texts. This book bears the stamp of that instruction.

The lesson was burned into my memory in the fall of 1989 . That season was remarkable for the political struggles that transformed the nations of Eastern and Central Europe, but I (also) recall it for my utter failure to engage students with the thought of Karl Marx. My course focused on a handful of "epic" theorists, taking them in chronological succession. It was late in the semester and well into those world-changing popular rebel- 
lions by the time we got to the works of the renowned theorist of revolution. My students were underwhelmed by the encounter. Their responses ranged from blank indifference to irritation. After all, wasn't every morning's headline a reminder that Marx's moment had passed, that his ideas had failed the test of time and experience? Why labor to make sense of such difficult writings? I responded to these questions like a scholar: I contextualized. Situating Marx in his time and place, reading him with and against the philosophical traditions he came out of, I tried to show what he had accomplished relative to his contemporaries and predecessors. As a pedagogical tactic, contextualization failed. Why should it have worked? The students were looking for someone relevant to their concerns. I eventually came to believe they were right.

Of course, one of the marks of a great text is that it can challenge readers' sense of what is relevant, unsettling certainties not only about prevailing answers but about what questions are worth asking. Powerful theories of the past instruct us by leading us out of the present. The most powerful of all, however, also lead us back to it. As they distance us from the positions offered in contemporary debates, they help us to scrutinize the very framework of agreement within which these debates take place. Their challenge to contemporary priorities begins from and, in the end, returns to questions that matter now. Or so I concluded in thinking about my time with those disgruntled students. Now, in my classes, texts from different eras and genres jostle against each other, arguing over questions and answers, problems and their definitions. Malcolm X questions Socrates. Aristotle meets Catharine MacKinnon. Tocqueville struggles with Foucault over problems of political subjectivity, while Marx interrogates the construction and elision of class identities in contemporary talk about "the economy," and Arendt converses with Toni Morrison about American narratives of belonging and freedom. Students still respond sometimes with puzzlement and irritation (as Socrates might ask, what worthwhile political pedagogy never irritates?). But they are rarely indifferent. The work they do in response to these staged encounters is often imperfectwhich keeps me usefully employed - yet it brings me satisfaction by offering engaged thinking that is at once theoretical and political.

Usually, this thinking ignores certain scholarly proprieties. The theorists brought into dialogue are frequently people who could never have met. They would have found it difficult to talk to each other. They differ in conclusions and assumptions, in standards of argument and evidence, in the epistemic or ontological structures within which their claims are articulated. Bringing their works together, and bringing them to bear on the present, requires one to slip through these barriers to exchange: the 
nuances of context are forsaken in the attempt to pursue problems that matter. And so I encourage students to exercise a certain freedom in reading. In making use of the texts, they run a few traffic lights. Running lights is a dangerous business, of course; there are reasons for the rules of the road. I try to make students aware of the dangers and reasons, but I also let them know that there is both pleasure and opportunity in taking certain risks, at least if these are taken skillfully. As Certeau puts it, in words that helped inspire these reflections, "reading ... introduces an 'art' which is anything but passive." "For those who are artful, there is room to move.

Tocqueville suggests that there is an "art of being free": freedom is a practice that requires study and skill. His analyses of political life look at the ways states and societies leave space or block opportunities for the exercise of this art. Can texts also foreclose or open such spaces? Might the arts of freedom and reading be connected? I believe they are. Democratizing textual authority is crucial to democratizing political authority, for effective political agency depends on the ability to interpret the signs that direct traffic through the polity and to inscribe one's signature upon the world. The connection is easiest to see in the classroom. There, to change reading practices is to change relations among students, relations that - in a limited way and in a special environment, to be sure-are necessarily political. Who talks, how they talk, and what they are willing and able to talk about are fundamentally shaped by a course's types and ways of reading. Encouraging the reading body to be freer in its movements promotes the kinds of relationships and conversations that make teaching worthwhile. Cultivating the art that Certeau calls "reading as poaching" makes it easier to learn something about the other arts of politics: this way of reading opens up questions about the practice of freedom even as it enables readers to experience that practice.

Thanks, in part, to the instruction provided by resistant students, this approach has filtered into my writing as well. I seek freedom in these pages, and the search is conducted in similar ways: there is much poaching in the chapters that follow, and they at times show a studied disregard for the red lights of scholarly caution. My themes are pursued through extended encounters with Tocqueville, Marx, and Arendt. The reasons for this selection will be explored more fully in Chapter I. Let it suffice now to say that their rich works - which reveal much about the authority of texts and the textualization of authority-instruct us through their insights into the art of being free and their efforts to evade certain political questions. To get the most of my encounters with them, I try to extend the insights and expose the evasions through my own art of reading freely. Although this book proceeds through a few intensive readings, its pur- 


\section{xii Preface}

pose is to address present predicaments in the theory and practice of freedom and democracy. The authors engaged speak powerfully and provocatively to us, across those barriers of time, beyond their immediate concerns, even against their own most explicit purposes and conclusions. To make the most of what they have to say, it is sometimes useful to emancipate the texts from their original places (it is not only the reading body that moves: as Edward Said reminds us, theory also travels). ${ }^{2}$ At a time when - as we will see - the very notion of place is increasingly problematic, when the locations of politics are multiplying and the politics of location are unusually complex, confusing, and contested, this emancipation is called for as never before. Ours is a moment in which the best way to pay tribute to one's source of intellectual inspiration is, as Foucault once remarked of his own appropriation of Nietzsche's work, "to use it, deform it, make it groan and protest": in seeking to expand the contemporary practice of liberty, it is necessary to take liberties with the theories handed down from previous ages. ${ }^{3}$

This literary tactic of taking liberties is enabled by an approach that could be called "serious irony." 4 Though serious about the texts' achievements and limitations, it is ironic in its refusal to be governed entirely by them. While written under the tutelage of these authors and allied to some of their basic insights and commitments, it deploys them in arguments that differ willfully and at times perversely from the originals. There is an underlying faithfulness in my readings but they are, to borrow from Donna Haraway's discussion of irony, "perhaps more faithful as blasphemy is faithful, than as reverent worship and identification." ${ }^{5}$ Irony is not a science or a method. In interpretation, as in politics, being free with others is - to say it again - a matter of art. That art is open, partial, for "nothing that is complete breathes." ${ }^{6}$ If there is a "methodological" principle guiding this work, it is the deliberate avoidance of interpretive and theoretical systems. The chapters that follow are a series of exercises in thought, textual skirmishes in which the goal is the emancipation of particular insights that can be bent toward contemporary purposes. But if serious irony requires one to read against the grain, it is not ventriloquism: this approach neither presupposes nor sustains the conviction that any text always means anything one says it does. If that were true, there would be nothing to learn, no reason to undertake the patient and difficult work of reading, to engage the thought of these thinkers rather than others. I turn to Tocqueville, Marx, and Arendt because they have something important to teach (though the lessons we need from them now are not always the ones most valued by the authors or their previous readers), 
and that conviction is what sustains the interplay of criticism, approbation, and appropriation that is the main substance of the pages that follow.

Those pages conduct a search for scraps-not whole cloth but fragments that, from book to book and theorist to theorist, can be stitched together into something different from what was intended by the original makers. As any number of writers have remarked since Lévi-Strauss made bricolage a celebrated trope, and as the great collective project of quilting to re-member lives lost to AIDS has shown with particular poignancy in recent years, finding a past that can speak to our time is work for political bricoleurs. ${ }^{7}$ If, as Arendt argued some years ago, the threads tying us to "the Great Tradition" of political thought have long been irreparably broken, then we have nothing to lose by taking up the impure work of sampling: the bits and pieces from which we can invent a usable past will otherwise go to waste, or will get reified, fetishized, made the basis of nostalgic and ultimately doomed attempts to recover worlds gone by. ${ }^{8}$ Why sanctify what is lost to us? Scholars of political thought have worshipped long enough; perhaps a bit of interpretive blasphemy can aid the work of freedom. After all, there are liberties to be taken.

Williamstown, Massachusetts

Mark ReinhardT 
